\title{
Visualization of Impact Force by Using Pressure Sensitive Paper
}

by

\author{
Kinya OGAWA *
}

To characterize damage and deformation in an impacted area of structure caused by flying foreign objects, it is fundamentally needed to measure the acting force and its distribution over the area. In the present experiments, it was attempted to identify visually the impact force using the pressure sensitive paper 'Prescale'. A split Hopkinson pressure bar method was used to evaluate the sensitivity of the paper under impact loading. It is found that the pressure sensitive paper instantaneously responds even for the impact loading of which duration is several hundred microseconds, while the sensitivity is significantly reduced when compared to the quasi-static loading. Hertzian impact tests were tried to visually evaluate pressure distributions using the pressure sensitive paper, and the experimental results were discussed.

Key words : Visualization, Impact force, Pressure sensitive paper, Split-Hopkinson bar, Duration of impact

\section{1 緒言}

飛米物によって棈造物に引き起こされる変形や損傷を 明らかにするためには，衝突面に衝く衝撃力を知ること が基本的に必要であり，压電フィルムを用いることなど が試みられているが ${ }^{1)} 2$ 次元的な圧力状態を直接測定す ることは極めて困難であり，有効な手段は未だに開発さ れていない。マイクロカプセルを塗布した感在紙2),31 は ノーカーボン複写紙として広く用いられ，Fig. 1 に示す ように, 内包されていた発色剂が浸潤して顕色剂と反応 し発色する。ここに取り上げた感圧紙は，種々の粒度の マイクロカプセルを調合することによって压力值と発色 濃度の関係を広範䧃に変化させ, 発色濃度を測定するこ とによって逆に厤力值を算定しようとするものである。 Fig. 2 には，フィルム上に塗布された低圧力測定用のマ イクロカプセルの SEM 写真走し, それらの粒度分布 をFig. 3 に示す。これらのマイクロカプセルは測定する 压力域に応じて，種々のバインダーによって結合され， フィルム上に塗布される。静的な加压によって発色する これらの感死紙をゴルフクラブや野球のバットなどの打 撃面に貼付し，打撃点を知るなど，衝撃圧の場合にも利

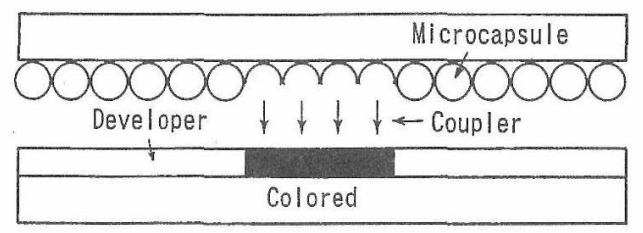

Fig. 1. Structure and mechanism of pressure sensitive paper.
用することが進められてはいるが, 衝撃力を定量的に把 握するまでには至っていない。マイクロカプセルの破㗒 は, 温度, 湿度などの環境条件に加えて, 圧力の負荷速 度，乤の持続時間にも依存すると考えられるから，これ らの力学的条件での発色濃度と压」の関係孛求めること が衝撃力を推定するためには必要となる。そこで，本論 文に括いては，衝撃によって発生する最高圧力を感圧紙 によって可視的に検知することを目指し，圧縮型ホプキ ンソン棒法 ${ }^{4)}$ を利用して衝撃圧下での感圧紙の応答性と 感度を調べ，衝撃圧の可視化測定における問題点を明ら かにする。

\section{2 試料および試験方法}

用いた感圧紙はプレスケール（富士写真フィルム製） であり，低圧用 LW，中圧用 MW 扣よび MS，高圧用

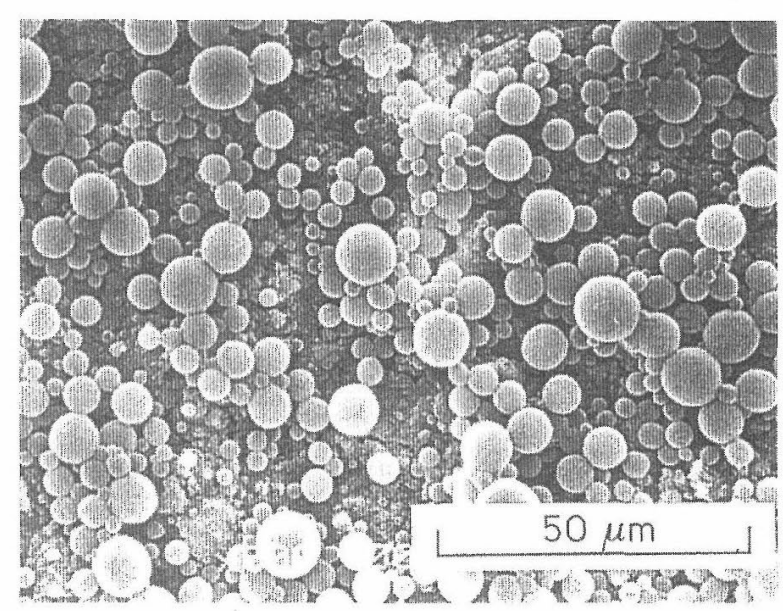

Fig. 2. Microstructure of "Prescale" by SEM.

\footnotetext{
原稿受理 平成 9 年 5 月 6 口 Received May 6, 1997

* 正 会 員 京都大学大学院工学研究科航空宇宙工学尃攻 ₹606-01 京都市左京区吉田本町, Div. of Aero- \& Astron., Grad. School of Kyoto Univ., Sakyo-ku, Kyoto, 606-01
} 


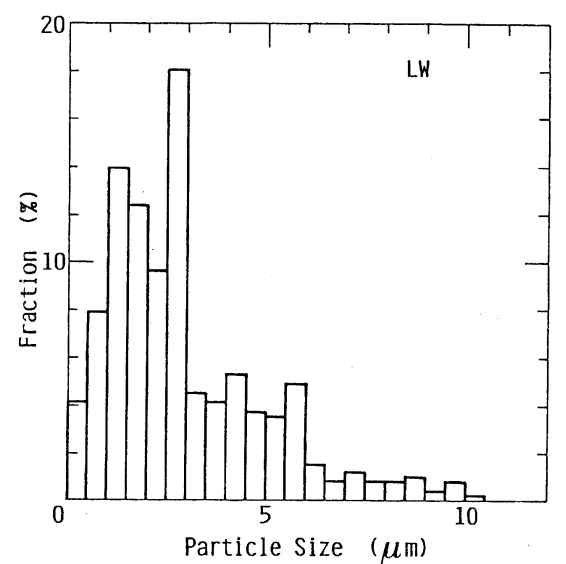

Fig. 3. Size distribution of microcapsules.

HS の合計四種類である．LW と MW は発色剂を内包す るマイクロカプセルを塗布したフィルムと，顕色剂を塗 布したフィルムとの二枚のシートを組み合わせて圧力を 測定するッーシートタイプ, MS と HS はマイクロカプ 七ルと顕色剂とを混合して一枚のフィルムに塗布したモ ノシートタイプであり，いずれのフィルムも厚さは（90 土5） $\mu \mathrm{m}$ である。 与えられた圧力と発色濃度関係を確認 するために行った静的な加圧試験には万能試験機（オ一 トグラフ）を用い，端面を研削仕上げした直径 $20 \mathrm{~mm}$ の円板状の圧盤間に二枚の PET（ポリエチレンテレフタ レート）製保護シート（厚さ $70 \mu \mathrm{m} ） に$ に挟まれた感圧紙 を挿入して加圧した。所定の值まで昇圧するに要した時 間は 2 分であり，所定の圧力に 2 分間保持後，5 10 秒 以内に減圧した。

衝撃的な加圧には Fig. 4 に示すホプキンソン棒型衝撃 圧縮試験装置を用いた。端面を十分に平滑に仕上げた入， 出力棒を用いても, 一様な衝撃圧を試験面に負荷するこ とは一般に極めて難しく, 各棒の軸芯を高度に一致させ る必要がある。 また, 入, 出力棒に曲洒撃の生じるこ とも防止しなけ机ばならない，そこで，真直性と真円度 の高いスライドシャフト（S45C 製, 表面硬質クロムメ ッキ，直径 $20 \mathrm{~mm}$ ）を応力棒として用い，支持部にはス ライドベアリングを設置して応力棒の軸方向への滑らか な動きを確保するとともに曲げの発生を防止した。 また， 長さ $500 \mathrm{~mm}$ の打ち出し棒先端を曲面に加工し, 入力棒 端面の中心が衝突点となるようにした，次に，試験面で ある入力棒（長さ $1250 \mathrm{~mm}$ ） と出力棒（長さ $1000 \mathrm{~mm}$ ） の端面間に感圧紙を挿入し, 衝撃を加えて発色痕を調べ, 支持部を微動しながら最良な加圧状態になるまで調整を 繰り返した。 入力棒と出力棒に貼付したひずみゲージに よって入射波 $\sigma_{I}$, 反射波 $\sigma_{R}$, 透過波 $\sigma_{T}$, を捉え，入， 出力棒間に挿入した感圧紙に加わった衝撃圧 $P$ を次式 によって算出した.

$$
P=\left(\sigma_{I}+\sigma_{R}+\sigma_{T}\right) / 2
$$

加圧後の感圧紙上に残された発色痕をイメージスキャ ナによって記録し，圧力画像解析装置 FPD-901（富士 写真フィルム製）によって圧力值の算出を行った。その

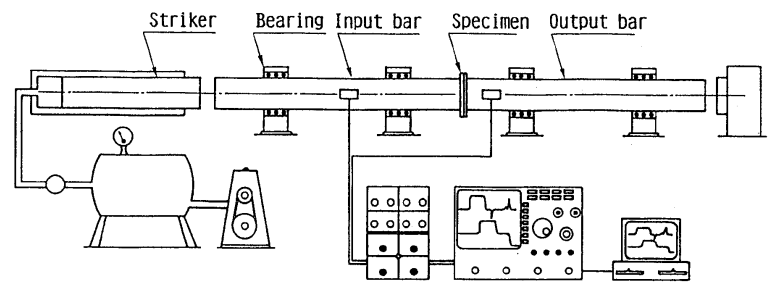

Fig. 4. Split-Hopkinson pressure bar apparatus and measuring devices.

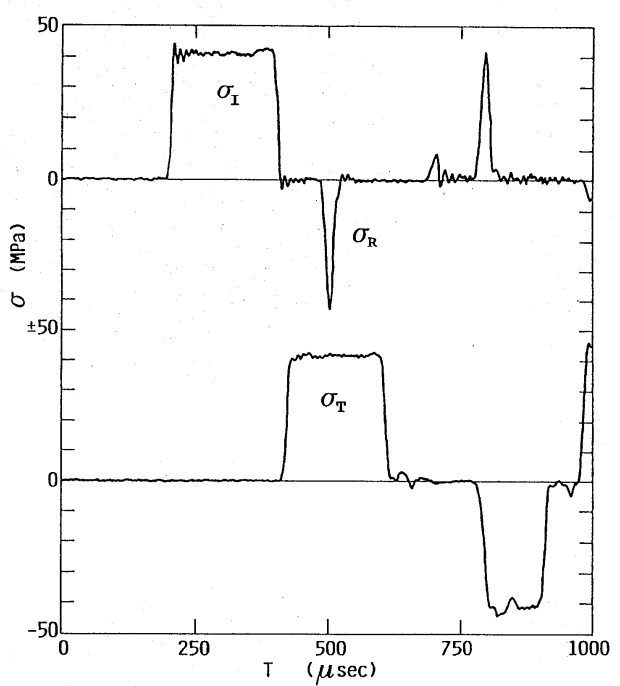

Fig. 5. Example of incident, reflected and transmitted stress waves.

際，各感圧紙に対して，静的な負荷の場合について予め 与えられている発色濃度-圧力校正関係を用いた。このよ うにして算出された圧力值を以下では圧力值 $P_{e}$ と呼び, 負荷した圧力值 $P_{a}$ と区別して示す。

また，非一様に分布する衝撃圧の発生例としてへルッ 接触問題を取り上げ，入力棒と，先端を曲率半径 $10 \mathrm{~mm}$ の球面に加工した出力棒との間に長さ $20 \mathrm{~mm}$, 直径 $20 \mathrm{~mm}$ の円柱状の試験片を設置し, 感圧紙を試験片と 出力棒間に挿入して衝突痕の可視化測定を行った。試験 片としては, 弾性係数が低く，かつヒステリシスが顕著 ではないポリアセタールホモポリマーを用い，広い弾性 接触面積を得ることを試みた。

\section{$3 \cdot 1$ 衝撃圧での感度}

Fig. 5 には衝撃加圧時の入射，反射，透過応力波の一

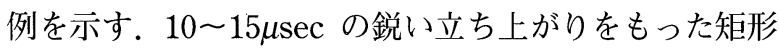
状の応力波が感圧紙に入射し，ほぼ同一の応力波が透過 している.このことから，一定な加圧状態が約 $200 \mu \mathrm{sec}$ の間, 持続していることが分かる. 衝撃の初期にはごく 僅かの反射波が観測されるが，これは感圧紙と応力棒の 端面との間に若干の間隙が最初存在していたことを示し ている。

Fig. 6 (a) には中圧用感圧紙上に残された発色痕内の圧 
力值 $P_{e}$ の分布を，比較的低い圧力と高い圧力の場合に ついてそれ癸机多色表小した。いずれの場合でも持続時 間 $200 \mu \mathrm{sec}$ の衝撃的な加圧に対しても，感圧紙が応答 し，試験面の直径と比べると $1.5 \%$ 程度人きいが，ほぼ 同寸江の明睹な発色痕を生じている。加圧面内の圧力分 布は完全な一様状態ではなく，止力が偏った領域が若干
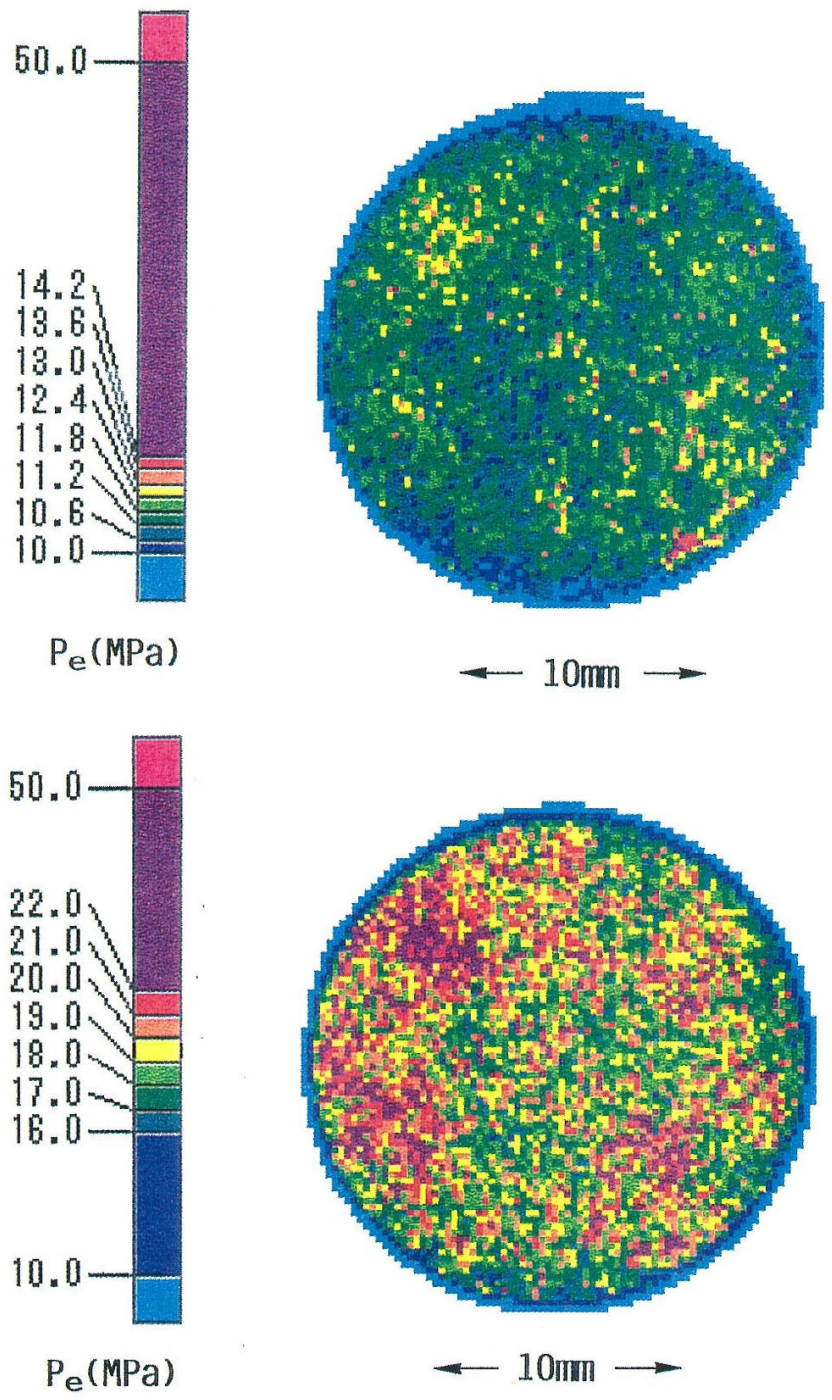

(a) Spatial distribution of pressure over impressions.

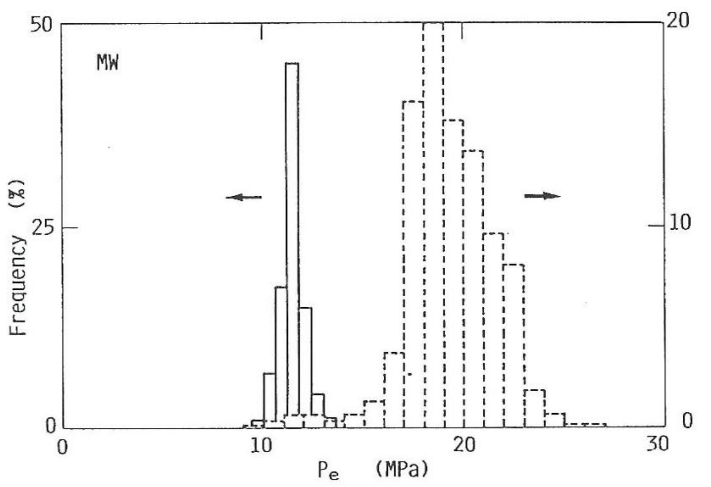

(b) Frequency distribution of pressure.

Fig. 6. Pressure distribution under impact loading.

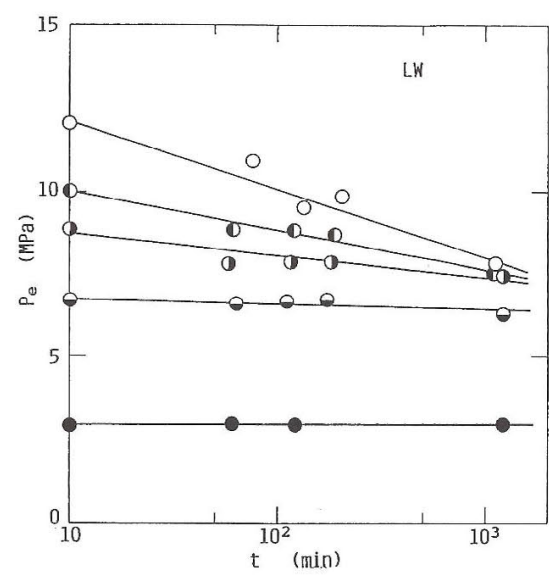

Fig. 7. Change in pressure sensitivity after elapsed time.

認められる。特に，圧力が高い場合には，中心付近の圧 力が低く，中心より離れた部分に高い圧力が認められる。 剛体壁に円柱が軸方向に衝突した場合，円柱表面で生じ た半径方向への膨張波が円柱内部へ伝ぱし，中心軸上に 集中した時に軸方向に過剰な収縮が起こり，衝突面中心 付近が壁から離れる現象が生じることが数值解析によっ て示されている.5)，6）このような現象は衝突速度が大きい ほど顕著となり，衝撃持続時間中何度か繰り返されるた め, 結果的に中心部での圧力の持続時間を短くすること になり，そこでの発色濃度を低下させていると考えられ る。ただし，高圧領域が完全に同心円状に生じているわ けではないことから，偏心荷重の影響も若干現れている ものと考えられる。一方，周辺部に見られる低圧域は保 護フィルムや, 感圧紙のベースを介してマイクロカプセ ルを加圧しているため円柱の外側にも加圧域が広がった ために生じたと考えられる。

Fig. 6 (b) には面内の圧力分布頻度を示した。これより， 半値幅で圧力值 $P_{e}$ の精度を表すと，圧力の低い場合に は土 $1 \mathrm{MPa}$ 程度，高い場合には土 $2 \mathrm{MPa}$ 程度であること が分かる。このように, 加圧面内での圧力分布には若干 不均一性が見られるが，ここでは接触面にわたって平均 した值を用いて $P_{e}$ を求めた

Fig. 7 には, 感圧紙上の発色痕より求めた圷力值 $P_{e}$ と加圧後の経過時間の関係を低圧用感圧紙 LW の場合 について示す。負荷圧 $P_{a}$ が大きい場合には，時間経過 と共に圧力值は急激に低下寸ることが分かる。このよう な現象が生じる原因は不明であるが，実用上は，負荷後， 測定までに要した時間を明確にすることが圧力值算定の ために極めて重要である。一方，負荷圧が大きくない場 合には，時間の経過に対しても圧力值 $P_{e}$ の変化は小さ く，測定までの経過時間の影響はほとんど考慮しなくて も良いことが分かる。

Fig. 8 (a), (b), (c), (d) には, $P_{a}$ と $P_{e}$ の関係を各感圧 紙の場合について示す。低圧用 LW, 中圧用 MW のッ ーシートタイプでは負荷後の経過時間が $t=10 \mathrm{~min} て ゙ の$ 結 果告丸で, $t \fallingdotseq 10^{3} \mathrm{~min}$ での結果告丸で示すが，高負 


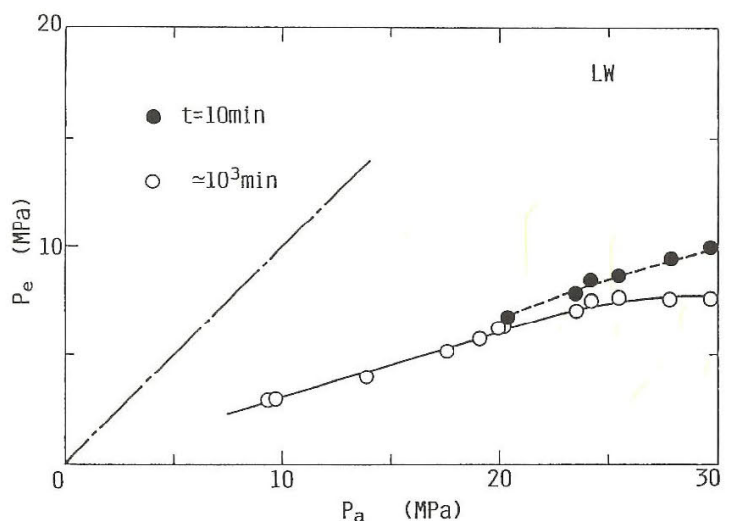

(a)

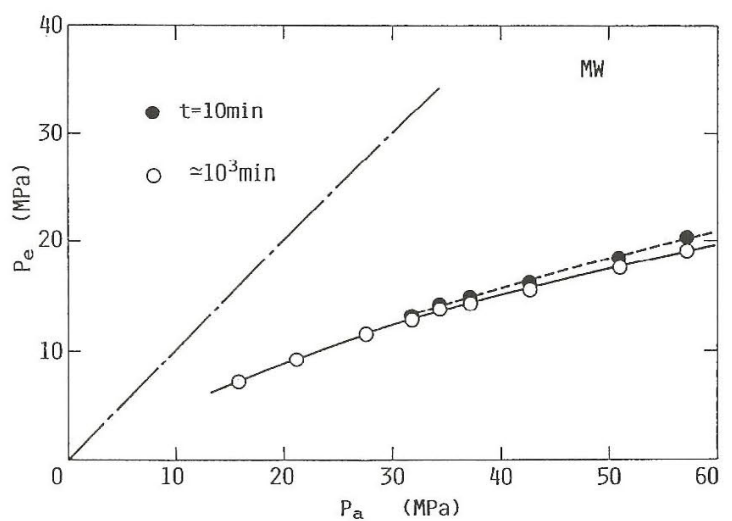

(b)

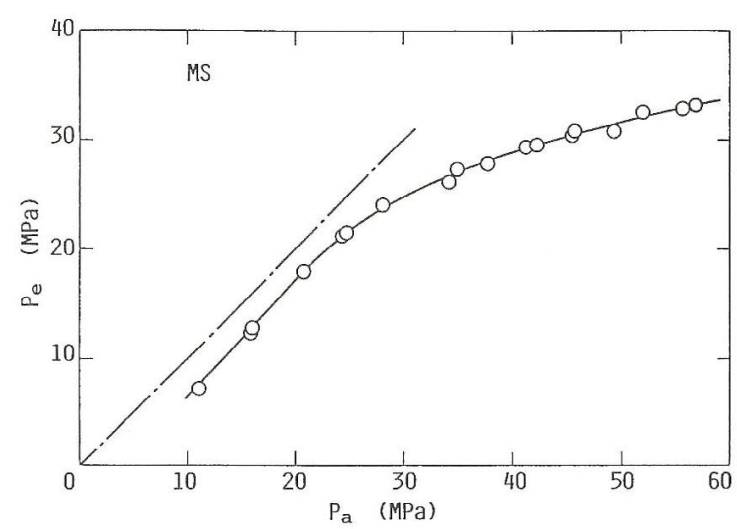

(c)

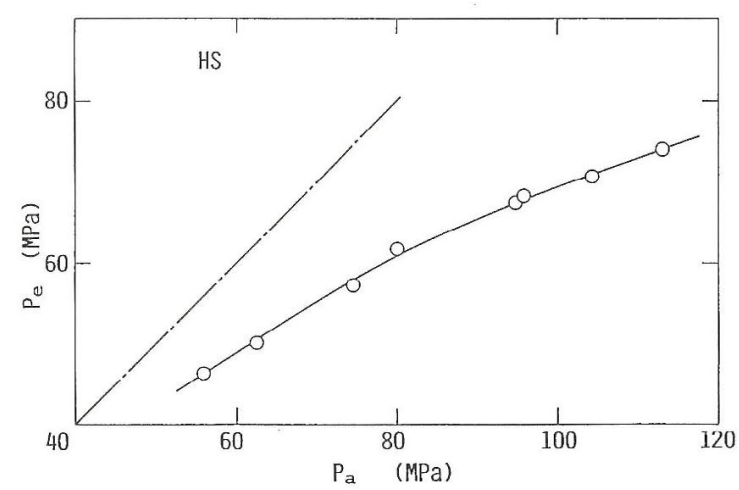

(d)

Fig. 8. Relationship between the applied pressure, $P_{a}$, and the estimated pressure, $P_{e}$, for LW in (a), MW in (b), MS in (c), and HS in (d), respectively.
荷圧域では経過時間の影響が見られる。これに対して， 中圧用 MS, 高圧用 HS のモノシートタイプでは全圧力 域に渡って経過時間による感度の卒化はほとんど見られ ない，穴れでれの感圧紙についてデー夕点を連帢ると， それ只れ一本の滑らかな曲線が得られ，衝撃圧に刘する $P_{a}-P_{e}$ 関係が一意的に決定できる。従って, これらの関 係に基づいて，発色濃度から衝撃圧を知ることができ， 可視的に衝撃力を捉えることができる。いずれの感上紙 の場合も, 負荷した圧力 $P_{a}$ に対して圧力值 $P_{e}$ は低く, 圧力值 $P_{a}$ が大きくなるにしたがって発色濃度の変化が 小さくなり，結果的に圧力值 $P_{e}$ がほとんど変化しなく なるため，关の食い違いは大きくなる、特に、ッーシー トタイプの場合には全圧力域に渡って著しい。これは， ッーシートタイプでは発色剂と顕色剂との反応に必要な 接触時間に比べて衝撃持続時間が短いため, 発色が十分 に行われないためと考えられる。このように，衝撃圧の 場合には，静的な負荷圧力の場合について求められた発 色濃度-圧力関係に基づいて評価した圧力 $P_{e}$ は実際に負 荷された压力值を著しく過小評価することになり，負荷 時間を考慮した発色濃度一圧力関係を用いる必要がある ことが分かる。

ここに示した関係は負荷持続時間が $200 \mu \mathrm{sec}$ の場合 であるが，一般的な衝突現象においては衝撃压の大きさ は時間的に変化し, 衝撃圧を受ける領域も時間的に変化 するため，穴れ穽れの領域での衝撃圧の持続時間も異な

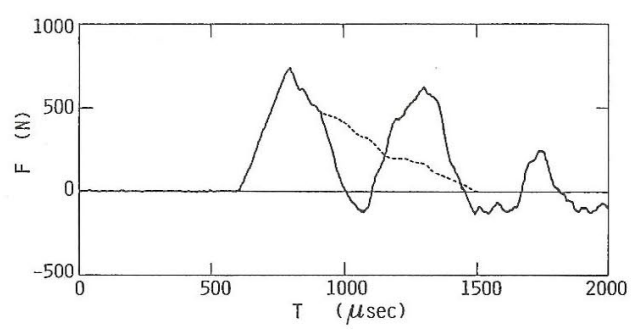

Fig. 9. Transmitted stress wave form and loading history for impulsive point contact.

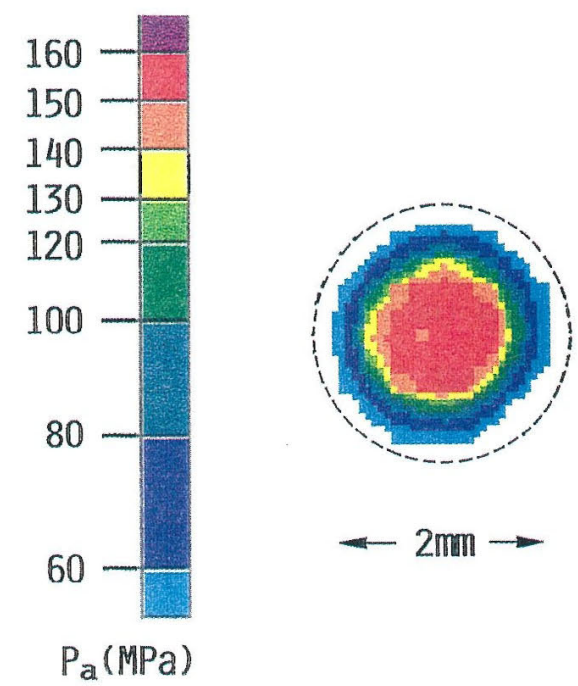

Fig. 10. Dynamic impression and pressure distribution caused by impulsive point contact. 


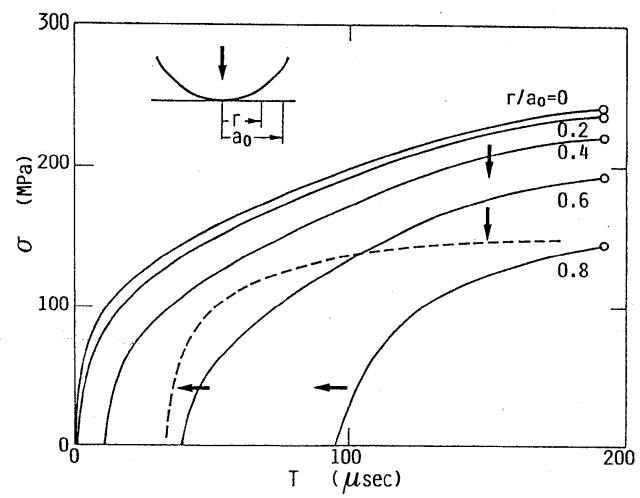

Fig. 11. Pressure history for Hertzian contact.

つてくる，そこで，このような場合について上に得られ た $P_{a}-P_{e}$ 関係を用いて衝撃圧の測定が可能であるか否 かを調べる。

\section{$3 \cdot 2$ 変動衝撃圧の測定}

本研究で行ったように，一様な棒の先端を球面にし， これを平面に衝突させる場合では, ヘルッ接触点での全 荷重をこれより離れた一様棒の部分で検出した荷重によ って近似的に評価することができる.?

Fig. 9 には, 出力棒で観察された透過応力波形を実 線で示し，自由端よりの反射波を考慮して求めた全荷重 履歴を破線で示す。最高荷重値に達するまでの時間は約 $200 \mu \mathrm{sec}$ であり，ほぼ同程度の除荷過程が続く． Fig. 10 には，その際感圧紙上に残された压痕を示すととも に, 先に求めた衝撃圧での $P_{a}-P_{e}$ 関係を用いて求めた 圧力分布を示す．この圧力分布より求めた荷重值は Fig. 9 での最高荷重值の打よそ $1 / 2$ となり，大きな食い違 いが見られた。また，ほぼ円形の圧痕の半径は，以下に 述べるへルツの弾性接触論から予測される, 最高荷重值 での接触円の半径（図中に破線で示す）に比べて小 さい.

いま，ターゲットとして用いた試験片ポリアセタール が弾性変形のみを生じて打り, 静的な取り扱いができる と仮定すると, 接触点の中央から半径 $r$ での圧力 $P$. は次 式で与えられる.

$$
P=\left(3 F /\left(2 \pi a_{0}^{2}\right)\right) \sqrt{1-\left(r / a_{0}\right)^{2}}
$$

ここで, $F$ は荷重, $a_{0}$ は最高荷重值での接触面の半径 であり, 次式で与えられる.

$$
\begin{aligned}
& a_{0}=1.4645 \sqrt[3]{3 F\left(\delta_{1}+\delta_{2}\right) R / 4} \\
& \delta_{1}=\left(1-\mu_{1}^{2}\right) /\left(E_{1} \pi\right), \delta_{2}=\left(1-\mu_{2}^{2}\right) /\left(E_{2} \pi\right)
\end{aligned}
$$

$R$ は球面の半径 $(10 \mathrm{~mm})$ であり, $E_{1}, \mu_{1} ; E_{2}, \mu_{2}$ は 試験片と棒のそれぞれヤング率とポアッソン比である. 試験片については実測值, $E_{1}=3 \mathrm{GPa}, \mu_{1}=0.22$, 棒に ついては $E_{2}=2.06 \times 10^{3} \mathrm{GPa}, \mu_{2}=0.3$ を用い, Fig. 9 で の増荷重時の圧力変化を $\left(r / a_{0}\right)$ をパラメータにして Fig. 11 に示す. 各位置での圧力は時間遅れを伴いなが ら初期には急激に増加したのち, 引き続き暫増してゆく. ここには最高荷重までの計算を示したが，弾性的な除荷

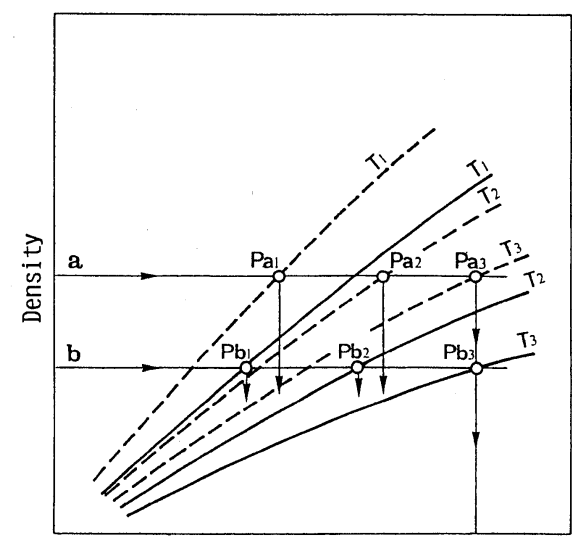

Fig. 12. Schematic presentation of dual-sheet method to simultaneously evaluate duration and magnitude of impact.

が引き続き起こるとすると，ここに示したと同じ過程が 逆に進行することになる，従って，中心部では高い圧力 を長時間受けるが，周辺部に近付くにつれて衝撃圧は低 くなり，㶢の持続時間は極端に短くなる。

実際には試験片表面には永久的な圧痕が認められ，塑 性変形が生じていることを示している。従って, 塑性変 形を生じた部分での圧力は計算結果に比べて低下し，よ り広い領域での変形を引き起こす。のため，破線で定 性的に示したように，各領域はより低い圧力を，より長 時間負荷されることになる，それにも拘わらず，感圧紙 上の圧痕が小さく，かつ，予測される荷重值が実際に負 荷した荷重に比べて著しく低いのは，接触部の周辺に近 い領域では，衝撃圧の持続時間が短く，それに伴って感 圧紙の発色濃度が低下し, 結果的に感度が低下している ものと考えられる．このため，広い面積を占めるこのよ うな領域での圧力評価の違いが荷重算出に際して大きな 誤差をもたらしたものと考えられる.

このように，衝撃圧の測定にプレスケールを利用して 衝撃力の可視化を実現するためには，持続時間をパラメ 一ターにした感度補正関係を実験的に求める必要があ る。午の際，重要な点は，そのような補正関係が求めら れたとしても，注目する場所での衝撃圧の持続時間を同 時に求めることが必要になる点である。このような問題 を解決する一つの手法としては，二種類の感圧紙を用い ることが考えられる。即ち，Fig. 12 に示すように，持 続時間による衝撃压の感度変化が異なった二種類の感圧 紙（実線と破線で示す）を重ね合わせて圧力測定を行 い，それぞれの発色濃度 $\mathbf{a} ， \mathbf{b}$ が得られたとする。この とき，両方の感圧紙は同じ衝撃圧を同じ持続時間経験し ているから，持続時間をパラメータとして $T_{1}, T_{2}, T_{3}$, と変化させながら，圧力値を算定して蛙ば，図中に示 すように，二種類の感圧紙について同一の持続時間と同 一の衝撃圧を与える点（図では持続時間 $T_{3}$, 衝撃圧 $P a_{3}=P b_{3}$ の点）が必ず存在し，これらを求めることが 出来るはずである。 


\section{4 結 論}

感圧紙プレスケールを用いて衝撃力の可視化を実現す るため, 衝撃圧下での感度と応答性を調べた，得られた 結果は以下の通りである.

(1) 感圧紙プレスケールは数百 $\mu \mathrm{sec}$ の持続時間の衝 撃圧に対しても応答し，衝撃圧を可視的に捉えることが できる。

（2）衝撃圧下での発色濃度は静的な加圧の場合に比べ 低下するが，衝撃圧と濃度との間には感圧紙の種類に応 じて一意的な関係が成立する.

(3) これらの関係の持続時間に対する依存性を明らか にすることが，時間的に変化する衝撃力を可視的に測定 するために必要である.

本研究を遂行する上で, 感圧紙プレスケールと圧力画 像解析装置の提供をいただいた(㹯富士写真フィルム情報 記録紙部に対し深く感謝いたします。
参 考 文 献

1) A. L. Smith and D. J. Mee, J. Strain Anal. Engn. Design, 31, 463 (1996).

2）森賀弘文, “入門 特殊紙の化学”, p.29（1975）高分子刊 行会.

3）中村孝一, 紙パ技術協会誌，29，9（1975）.

4) F. E. Hauser, J. A. Simmons and J. E. Dorn, "Response of Metals to High Velocity Deformation”, Ed. by P. G. Shewmon and V. F. Zackay, p.93 (1961) Interscience Pub..

5) C. H. Karnes and L. D. Bertholf, "Inelastic Behavior of Solids”, Eds. M. F. Kannienen, W. F. Alder, A. R. Rosenfield and R. I. Jaffee, p.501 (1970) McGraw-Hill.

6) 田中吉之助, 黒川知明, 上田和永, 材料, 34, 1390 (1985).

7 ) W. Goldsmith, "Impact”, p.98 (1960) Arnold Pub..

8 ) W. Goldsmith, "Impact", p.88 (1960) Arnold Pub..

9) M. Kornhauser, J. Appl. Mech., 18, 251 (1951). 